\title{
THE APPLICATION FOR A PREDICTION OF THE COAL SPONTANEOUS IGNITION - PREDISAM
}

\author{
Vlastimil MONI, Petr KLOUDA \\ Brown Coal Research Institute j. s. c., Most \\ Jan BLATA, František HELEBRANT \\ VŠB-Technical University of Ostrava
}

\begin{abstract}
:
The article follows the research of the project number TA01020351 called "The research of possibilities when predicting steam origin and consequent spontaneous ignition of brown coal fuels" which was researched with the support of the Technological Agency in the Czech Republic in 2011-2014 in the connection with a realized technical research. Therefore, it gives a summary information about the evaluation of the risk degree for the origin of spontaneous ignitions of the brown coal. The presented way of evaluation is based on a numeric expression of a value for MHU criteria - the point load of particular indicators is added together with other results gained from this research project. Then, more information is taken from companies running the dumps of brown coal products - both for suppliers (mining companies) and big consumers (power engineering). The complex knowledge about prediction of the origin of the spontaneous ignition enables to make an early response to eliminate a threat of mining fire in open pit mines or on the dumps of coal products. Consequently, it reduces the risk of fire and breakdowns of transportation means DPD, heavy machines and preparation plants. The working injuries are reduced as well - burns by coal in fire or inhalation of gas products from imperfect combustion.
\end{abstract}

Key words: spontaneous ignition, brown coal, dumps, evaluation of prediction to spontaneous ignition

\section{INTRODUCTION}

The ČSN standard 441315 "Solid Fuels - Storage" determines ways how to store solid fuels and measures following economical and safe storage of solid fuels in energy production plants, industrial plants, coal storage facilities, consumers' coal basements. The standard orders a necessary surface check of the storage bodies of solid fuels, measurement of surface temperature and temperature measurement of inner points. The inner temperature measurement cannot sufficiently show the distribution of temperature in a storage body, and it is time and finance consuming when a satisfactorily dense network of measurement points is created and even technologically unreal in large bodies [1, $2,4,14,17]$. The recommended surface point temperature measurements are not able to give a complete image of the temperature state (in a real network of measurement points and real time). Thus they cannot detect all infusions in the area of irreversible temperature with a sufficient probability, they are not able to satisfactorily specify critical states, they thermal displays on the surface and inside a coal accumulation (storage etc.) especially in the relation to the inner state of the body, metaphorically to the applicability of the method to prognosticate steam creation in underground deposits. Neither do they include so far undefined influence on the development of steam.

This is proved by the fact that unexpected infusions and fires arise in spite of the check measurement required by the ČSN standard. Actual state of the observation of the thermal situation of the stored body does not enable its satisfactory identification from both space and time points of view, and so it does not thus enable an effective prediction of focus point arisng of infusions and fires and their following liquidation, either.

A $100 \%$ reliable method of an early indication of the spontaneous ignition process has not been found yet despite systematic efforts of researchers from all developed states of the world $[6,8,12]$. An evaluation of air composition and observing so called indication gases of spontaneous ignition is one of the most usual methods of the early indication and evaluation of the self-ignition state. Measurement of the temperature is a second possibility how to observe the development of the spontaneous ignition process $[5,9,10,12]$. Thermal measurement methods are based on an identification of the places in the observed location (coal seam, heap, etc.) with an anomalously increased temperature level against ambient mass. The project referenced above aimed at the parallel use of both mentioned methods relating to the early detection of spontaneous ignition process, to measure both mentioned parameters in one time domain and to create so a complex methodology enabling to early localise deposits in a critical steam state, especially from the point of view of areawidth, speed and accuracy of the localisation of potential place of the irreversible stem state tending to the spontaneous ignition $[3,7,11,15]$. The projected methodology should be applicable both at suppliers side (mining companies) and at consumers side (power industry). The applica- 
tion for the prediction of the coal spontaneous ignition PREDISAM is a part of an output pack of the project.

\section{OBSERVATION PROCEDURE OF SPONTANEOUS IGNITION PROCESS OF COAL MASS DUMP}

The following procedure was defined for the observation and following prediction of the spontaneous ignition process of brown coal mass $[16,17,18]$ :

1. Stacking up the dump.

2. Geodetic surveying the dump.

3. Thermal image of the dump.

4. Wind rosette for given period - from meteorologists.

5. Taking laboratory samples of coal from dump perimeter.

6. Defining measuring points:

- point 1 .... warmest in the direction of most often blowing wind with lowest speed,

- point 2 ..... maximum content of $\mathrm{CO}_{2}$ in $1 \mathrm{~m}$ depth,

- point 3 ..... maximum content of $\mathrm{CH}_{4}$ in $1 \mathrm{~m}$ depth,

- point 4 .... minimum content of $\mathrm{O}_{2}$ in $1 \mathrm{~m}$ depth,

- point 5 .... maximum content of $\mathrm{CO}$ in $1 \mathrm{~m}$ depth.

7. Create a file of input data -5 point with 5 quantities each $\left(\mathrm{T}, \mathrm{CO}_{2}, \mathrm{CH}_{4}, \mathrm{O}_{2}, \mathrm{CO}\right)$ and time $\mathrm{t}(\mathrm{t}=0)$.

8. Program for self-ignition prediction.

9. Implementation of measures proposed by program during observation process.

\section{CALCULATION OF GRADIENTS}

From parabolic trend:

Gradient

$$
g=2 \cdot a \cdot t_{n}+b
$$

Gradient

$$
\mathrm{g}=2 \cdot \mathrm{a} \cdot \mathrm{t}_{\mathrm{n}}+\mathrm{b}
$$

$$
\begin{aligned}
a=\frac{1}{n}\left(\sum_{i=1}^{n} y_{i}-b \sum_{1}^{n} x_{i}-c \sum_{1}^{n} x_{i}^{2}\right) \\
b=\frac{z_{3}}{z_{1}}-c \cdot \frac{z_{2}}{z_{1}} \\
c=\frac{z_{1} \cdot z_{6}-z_{3} \cdot z_{4}}{z_{1} \cdot z_{5}-z_{2} \cdot z_{4}} \\
z_{1}=\sum_{1}^{n} x_{i}^{2}-\frac{1}{n}\left(\sum_{1}^{n} x_{i}\right)^{2} \\
z_{2}=\sum_{1}^{n} x_{i}^{3}-\frac{1}{n} \sum_{1}^{n} x_{i}^{2} \sum_{i} x_{i} \\
z_{3}=\sum_{1}^{n} x_{i} y_{i}-\frac{1}{n} \sum_{1}^{n} x_{i} \sum_{z_{3}} y_{i} \\
z_{6}=\sum_{1}^{n} y_{i} x_{i}^{2}-\frac{1}{n} \sum_{1}^{n} y_{i} \sum_{1}^{n} x_{i}^{2} \\
z_{5}=\sum_{1}^{n} x_{i}^{4}-\frac{1}{n}\left(\sum_{1}^{n} x_{i}^{2}\right)
\end{aligned}
$$

where is.:

$\begin{array}{lll}X_{1}=t_{n-2} & y_{1}=T_{n-2} \\ X_{2}=t_{n-1} & y_{2}=T_{n-1} \\ X_{3}=t_{n} & Y_{3}=T_{n}\end{array} \quad$ y are quantities $T, C O_{2}, C O, O_{2}, C_{4}$. From linear trend:

$$
g=\frac{y_{n-1}-y_{n}}{\left(t_{n-1}-t_{n}\right)}
$$

where:

$y_{n} \quad \ldots . \quad$ quantity value of sample taken at time $t_{n}$,

$\mathrm{y}_{\mathrm{n}-1} \quad \ldots . . \quad$ quantity value of sample taken at time $\mathrm{t}_{\mathrm{n}-1}$,

$\mathrm{y}_{\mathrm{n}-2} \quad \ldots . . \quad$ quantity value of sample taken at time $t_{n-2}, t_{n}$,

$t_{n-1}, t_{n-2} \ldots . . \quad$ last, last but one, last but two time of sample

taking of quantity $y$.

Values of time $t$ are in days.

The gradient is calculated for all taking places.

The gradient is calculated for all quantities, ie y represents:

$\mathrm{T} \quad$..... temperature,

$\mathrm{CO}_{2} \quad \ldots . . \quad$ carbon dioxide,

$\mathrm{CH}_{4} \quad$..... methane,

$\mathrm{O}_{2} \quad$..... oxygen,

$\mathrm{CO} \quad$..... carbon monoxide.

Thus we get gradients $\mathrm{g}_{\mathrm{T}}, \mathrm{g}_{\mathrm{CO} 2}, \mathrm{~g}_{\mathrm{CH} 4}, \mathrm{~g}_{\mathrm{O} 2}, \mathrm{~g}_{\mathrm{CO}}$ for each sampling place, ie.. $\left(\mathrm{g}_{\mathrm{T}}, \mathrm{g}_{\mathrm{CO} 2}, \mathrm{~g}_{\mathrm{CH} 4}, \mathrm{~g}_{\mathrm{O} 2}, \mathrm{~g}_{\mathrm{CO}}\right)_{1},\left(\mathrm{~g}_{\mathrm{T}}, \mathrm{g}_{\mathrm{CO} 2}, \mathrm{~g}_{\mathrm{CH} 4}\right.$, $\left.\mathrm{g}_{\mathrm{O} 2}, \mathrm{~g}_{\mathrm{CO}}\right)_{2}, \ldots . .\left(\mathrm{g}_{\mathrm{T}}, \mathrm{g}_{\mathrm{CO} 2}, \mathrm{~g}_{\mathrm{CH}}, \mathrm{g}_{\mathrm{O} 2}, \mathrm{~g}_{\mathrm{CO}}\right)_{5}$.

\section{PREDICTION OF TIME TILL SPONTANEOUS IGNITION}

Predicted time period to spontaneous ignition:

$\mathrm{y}: \quad$ represents $\mathrm{T}, \mathrm{CO}_{2}, \mathrm{CH}_{4}, \mathrm{O}_{2}, \mathrm{CO}$.

Resulting predicted time period to spontaneous ignition:

$t_{\text {pred }}=\min \left[\left(t_{T}, t_{\mathrm{CO} 2}, t_{\mathrm{CH} 4}, t_{02}, t_{\mathrm{CO}}\right)_{1},\left(t_{T}, t_{\mathrm{CO} 2}, t_{\mathrm{CH} 4}, t_{\mathrm{O} 2}, t_{\mathrm{CO}}\right)_{2}\right.$, .... $\left.\left(\mathrm{t}_{\mathrm{T}}, \mathrm{t}_{\mathrm{CO} 2}, \mathrm{t}_{\mathrm{CH} 4}, \mathrm{t}_{\mathrm{O} 2}, \mathrm{t}_{\mathrm{CO}}\right)_{5}\right]$.

\section{SAMPLING PERIOD}

Next sample is to be taken after $t_{\text {sample }}$ [day] $t_{\text {sample }}=t_{\text {pred }} / 5$

Date of next sampling $=$ date of last sampling $+t_{\text {sample }}$.

Graph of time course of gradients of observed quantities (Fig. 1).

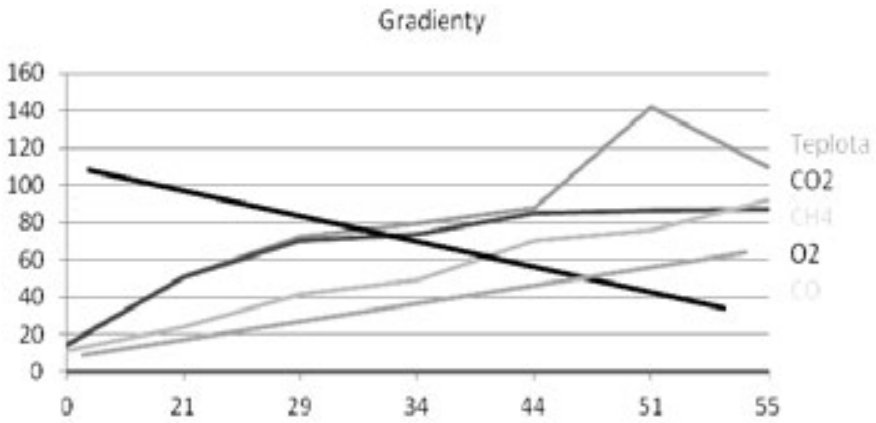

Fig. 1 Graph of time course of gradients of observed quantities

Maximums will be taken for individual curves of selected 5 observation points.

Graph of time course of values of observed quantities (Fig. 2).

Limit values for program testing:

$\mathrm{T}_{\lim }=92^{\circ} \mathrm{C}$

$\mathrm{CO}_{2 \lim }=20.5 \%$

$\mathrm{CH}_{4 \lim }=2.8 \%$

$\mathrm{O}_{2 \lim }=0.1 \%$

$\mathrm{CO}_{\lim }=35000 \mathrm{ppm}$. 


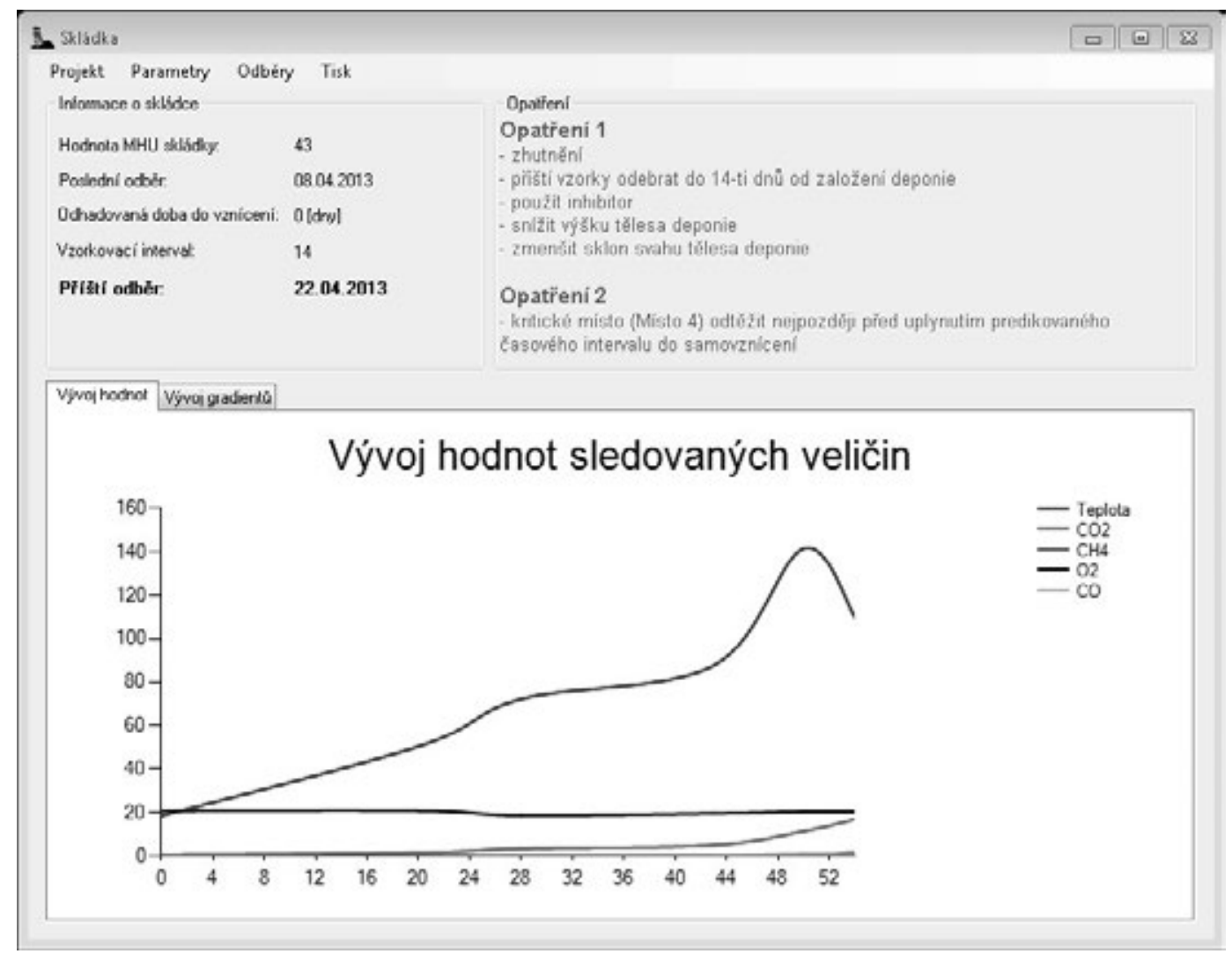

Fig. 2 Graph of time course of values of observed quantities

\section{APPLICATION FOR PREDICTION OF COAL SELF-IGNITION - PREDISAM}

Basic overviews of application are presented in the form of screenshots (Fig. 3).

\section{PROGRAM MAIN WINDOW}

Main window of the program represent a dump. Each dump is stored in an individual file of the project. The project can be saved and then read for following procession.

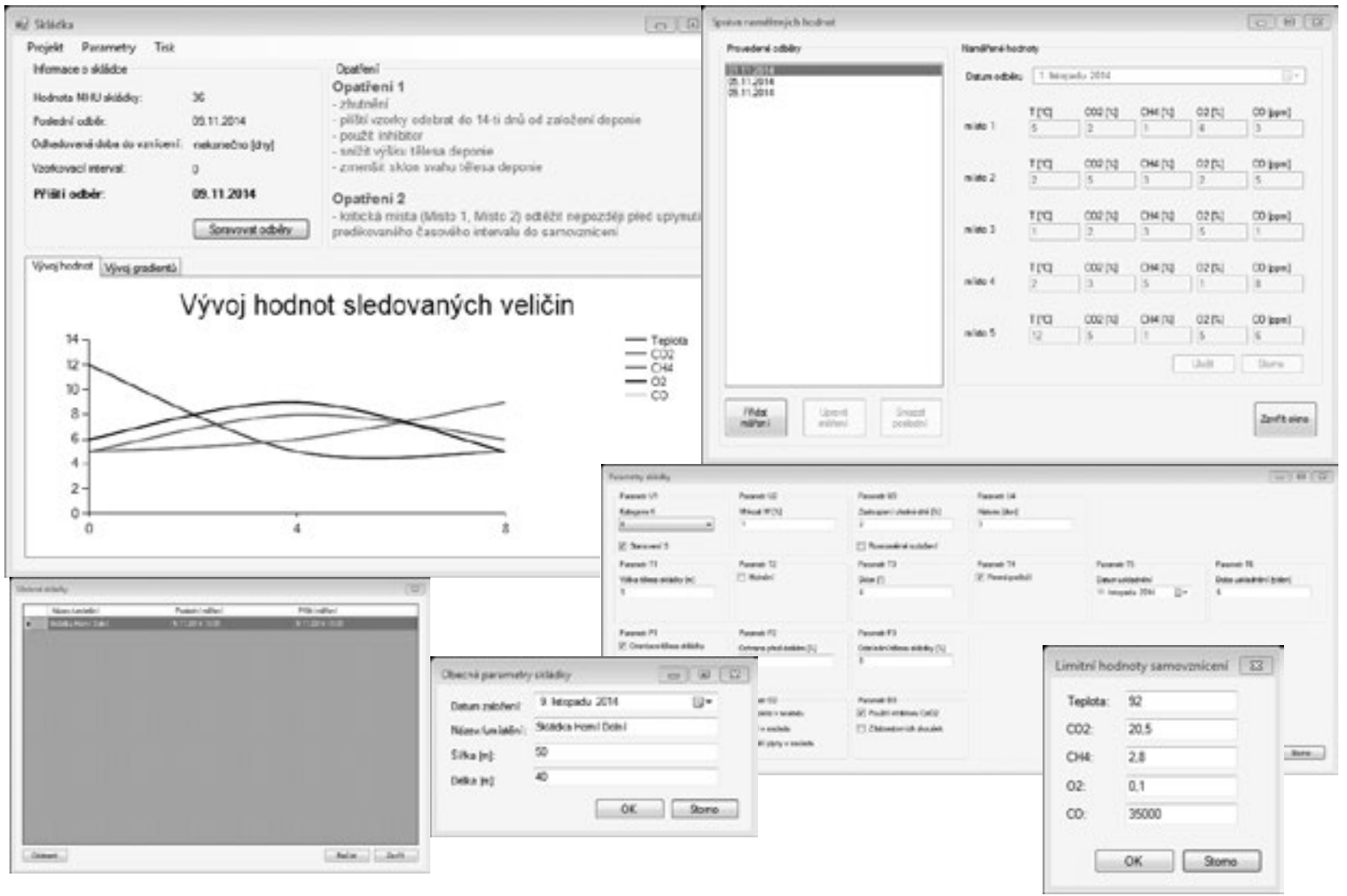

Fig. 3 Application for prediction of coal self-ignition - PREDISAM 
The dump has defined general parameters (name, size, location), parameters of limit values for spontaneous ignition and parameters of dumped coal. Sampled values are input to the dump project after measurement. A date of next measurement is estimated on the base of the values.

Program main window is divided into four parts:

- navigation menu,

- dump information,

- measures,

- graphs of quantity and gradient development.

\section{NAVIGATION MENU}

Navigation menu serves for control of the dump project, with help of which dump projects are saved and read, project parameters (general information, dump parameters, limit values) are defined and output reports are printed.

Parts of navigation menu are:

1. Project:

- Create new - cancelling actual project and a new is founded,

- Save - storing the project with all input values for next using,

- Read - section of project saved earlier,

- End - finishing the program.

2. Parameters:

- Change general information - definition of general parameters of the project,

- Change dump parameters - parameters of coal divided into some categories (U1, U2, U3,...),

- Change limit values - limit values for spontaneous ignition.

3. Sample taking,

4. Manage samples - input of measured values,

5. Print,

6. Introduction document - introduction report with dump parameters,

7. Measurement report - report with last measured values,

8. Summary report - summary report with dump parameters and all measured values.

\section{INFORMATION ABOUT DUMP}

Part of main window with dump information shows values calculated on base of input parameters. The MHU value is obtained from dump parameters configurable in the window „Parameters > Change dump parameters”. If the MHU value is higher than 35 , information about necessary measures is shown in the "Measures" main window part.

The last sample proceeds from measured values input in the "Management of measured values".

Estimated time till self-ignition, sampling period and date of the next sampling also proceeds from measured values. The date of next sampling is defined as $1 / 5$ of predicted time till self-ignition. The value is set to 0 for negative values of predicted time till self-ignition.

\section{Measures}

The program informs about necessary measures which must be taken if critical values are exceeded. Two measurements are possible:

- Measure 1 - obtained on base of the MHU value. The measure must be taken if the MHU is greater than 35,

- Measure 2 - obtained on base of the predicted time till self-ignition. The measure must be taken if the predicted time till self-ignition is less than 1.

\section{Graphs of quantity and gradient development}

Graphs with development of observed $\mathrm{T}, \mathrm{CO}_{2}, \mathrm{CH}_{4}, \mathrm{O}_{2}$ and $\mathrm{CO}$ quantities are shown in the lower part of the main window after values measured during sample taking are input. A second card shows the graph of gradient development on base of which the predicted time till self-ignition is calculated.

\section{Definition of project parameters}

\section{General parameters}

General parameters (Parameters > Change general information) define basic information about the dump. None of the information is used in calculations. The values are rather informative but the information is printed in reports. Name and location of the dump is used as an identification parameter for reading the dump project (Fig. 4).

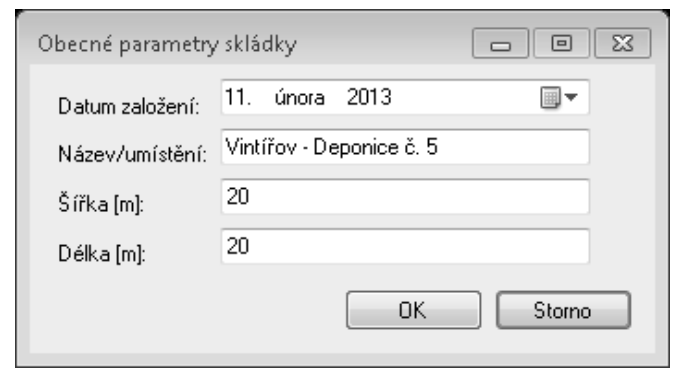

Fig. 4 General parameters and information about the dump

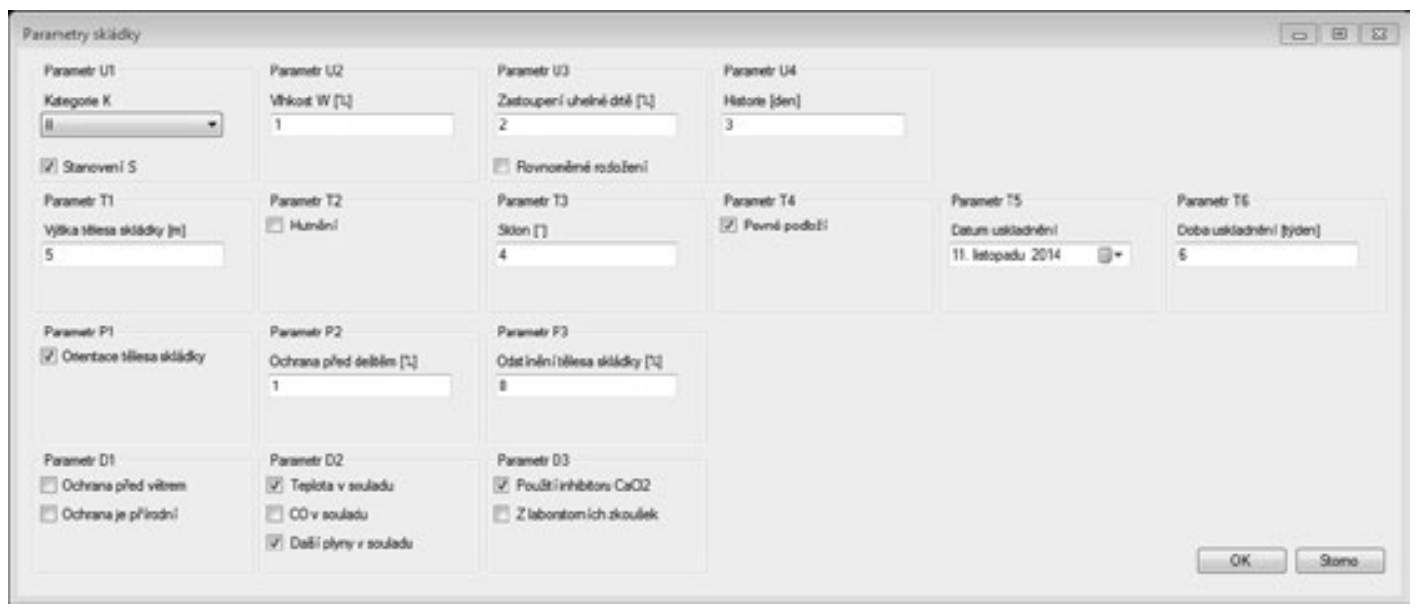




\section{Dump parameters}

The window with dump parameter definition (Parameters > change dump parameters) is a key window for the dump input parameter definition. The MHU value is then calculated from these values. The parameters are divided into four groups according to categories (U, T, P, D) (Fig. 5).

All ticking fields define YES value (ticked), NO (not ticked). Only a decimal number can be input to text fields. The decimal places separator is determined by the operating system localisation - comma is the separator on the Czech Windows (e.g. 10,5).

Table 1 shows the characteristics of the groups: $U, T, P$ and D.

\section{Parameters of limit values}

Parameters of limit values can be configured in a window accessible from the navigation menu (Parameters $>$ Change limit values). Critical values of the temperature, $\mathrm{CO}_{2}, \mathrm{CH}_{4}, \mathrm{O}_{2}$ and $\mathrm{CO}$ are configured here. If any limit is exceeded after inputting measured values at sampling, pro- gram informs about necessity of an appropriate measure. Decimal numbers are valid values.

\section{Management of sampling}

Sampling management window (Sampling > Manage samples) is a key element for inputting values obtained during sample taking (Fig. 6). The window is divided into two halves.

The left half of the window shows dates of earlier sample takings. Only last measurement may be changed or deleted. The reason is that measured values are depending on each other et estimating time till self-ignition.

After selecting the date of measurement in the left half part of the window, the values of this measurement are shown in the right part of the window. During the inspection of the measured values all elements are forbidden.

Input elements for reading values are activated by adding a new measurement or changing the last one. All input data may be integer or decimal numbers only. Date of sample taking must be later then the date of the last samples. The left part of the window is deactivated during activated right part of the window. For its activation the input values from the measurement must be saved or cancelled.

Table 1

Parameters of $U, T, P, D$ group

Parameters of $\mathrm{U}$ group

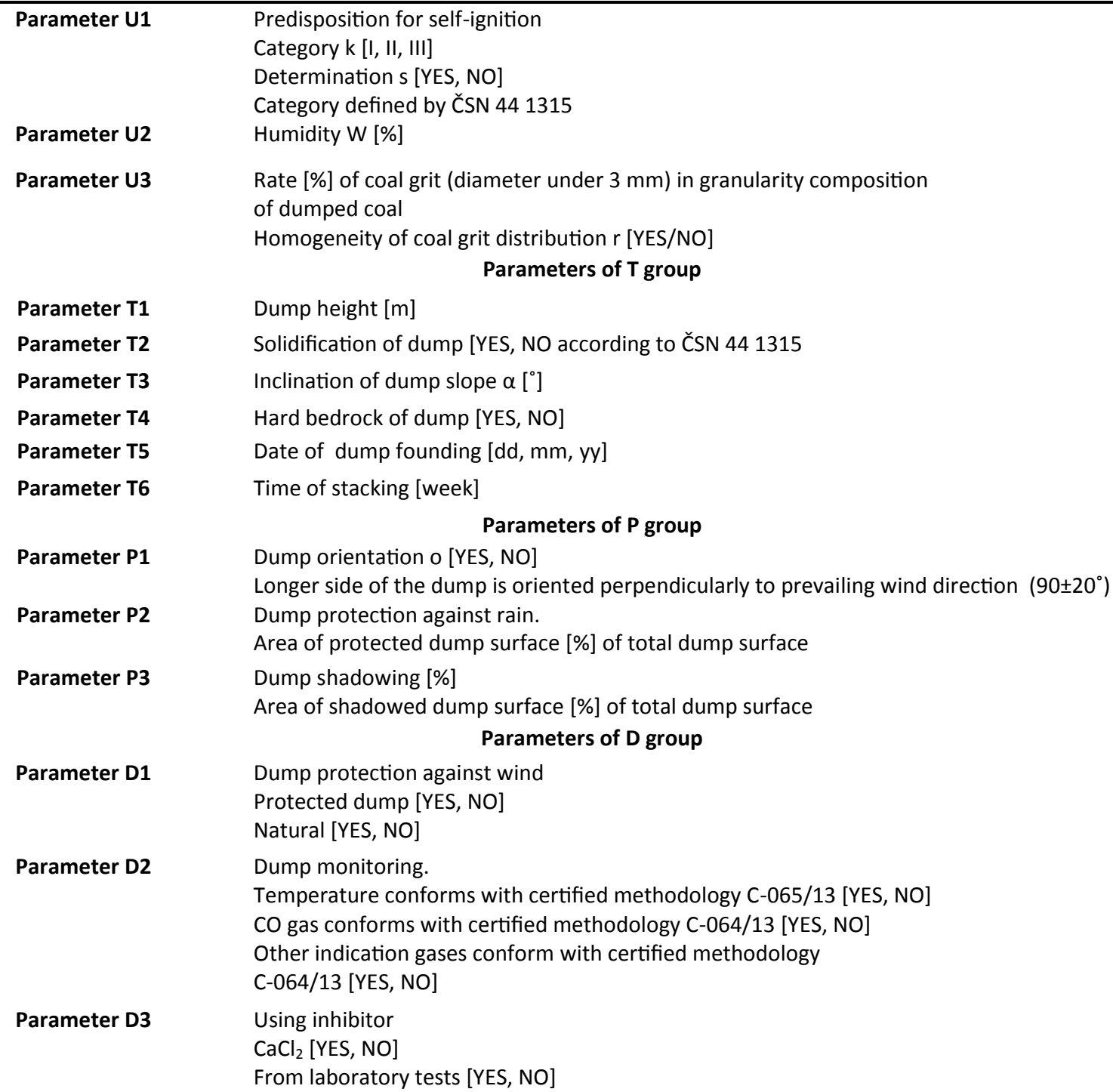




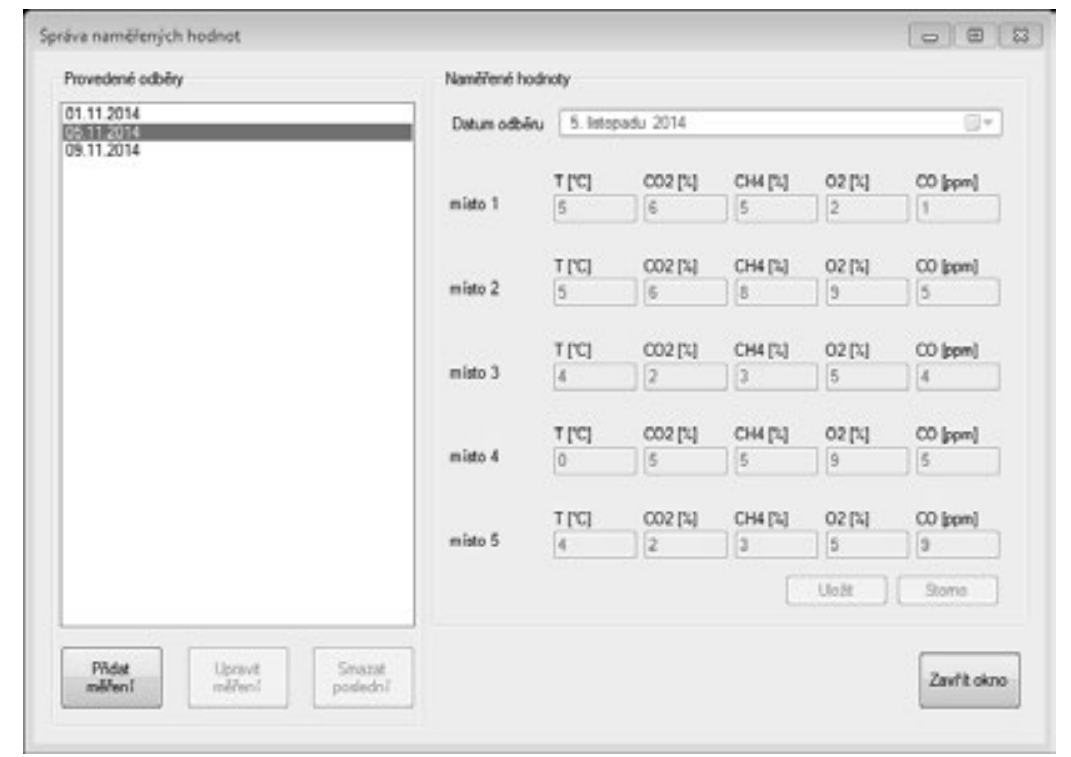

Fig. 6 Sampling management window

\section{CONCLUSION}

Conclusions can be made based on evaluation of significant number of acquired data (e.g. inner temperatures comprise almost 3.7 billion of values from 204 measuring places) which were taken during long-term field measurements and laboratory test of coal samples and subsequently processed into tables and graphs. The conclusions together with individual results of temperature and gas measurements are parts of separate outputs of the project (reports, studies, databases, catalogues, certified methodologies, utility models, software, etc).

The presented way of evaluation of danger rate of creation of spontaneous ignition process of brown coal enables to carry out an early measure to remove the threat of mine fire in the seam of open pit brown coal mines or on the heaps of coal deposits

\section{Acknowledgement}

The article was prepared in frame of the program ALPHA of the project TA01020351 with financial support from state budget funds by means of the TAČR agency.

\section{REFERENCES}

[1] B. Taraba, V. Voráček and V. Král. „Analýza případů samovzněcování uhlí $v$ dolech OKR - část I: Nový způsob hodnocení Rizika vzniku procesu samovznícení uhlí ve stěnových porubech", Uhlí, rudy, geologický průzkum, vol. 13, no. 11, 2006, pp. 34-37.

[2] B. Taraba, Z. Pavelek, J. Janek, V. Voráček and V. Král. „Analýza případů samovzněcování uhlí v dolech okr část II: Hodnocení požárního ohrožení porubu z hlediska provedení adekvátních represivních zásahů“, Uhlí, rudy, geologický průzkum, vol. 13, no. 12, 2006, pp. 28-31.

[3] B. Taraba. Nízkoteplotní oxidace a samovzněcování uhelné hmoty, Ostrava: Ostravská univerzita, 2003.

[4] V. Moni and B. Taraba. „Laboratorní šetření významu základních parametrů ovlivňujících oxidaci hnědých uhlí", Zpravodaj HU, no. 2, 2013, pp. 17-24.
[5] V. Dobal, I. Sýkorová, F. Valeška and B. Hemelíková. Metody stanovení aktivity hnědých uhlí ke kyslíku, Výzkumná zpráva ÚGG ČSAV, Praha, 1983.

[6] F. Akgün and A. Arisoy. „Effect of particle size on the spontaneous heating of a coal stockpile", Combustion and Flame, vol. 99, no. 1, 1994, pp. 137-146.

[7] Z. Michalec, V. Michalcová and B. Taraba. „Modelování vlivu parametrů uhelné skládky na dynamiku samovzněcovacího procesu“, Zpravodaj HU, no. 1, 2013, pp. 3-10.

[8] F. Akgün and R.H. Essenhigh. "Self-ignition characteristics of coal stockpiles: theoretical prediction from twodimensional unsteady-state model", Fuel, vol. 80, no. 3, 2001, pp. 409-415.

[9] V. Moni. „Vyhodnocení komplexních dlouhodobých měření na hnědouhelných skládkách“, Zpravodaj $H U$, no. 2, 2014, pp. 27-35.

[10] F. Helebrant, V. Moni, M. Hudeczek and P. Urban. Technická diagnostika a spolehlivost - V. Termografie, 1st ed., Ostrava: VŠB-Technická univerzita Ostrava, 2008.

[11] B. Taraba. Nízkoteplotní oxidace a samovzněcování uhelné hmoty, Ostrava: Ostravská univerzita, 2003.

[12] B. Taraba. „Reversible and irreversible interaction of oxygen with coal using pulse flow calorimetry", Fuel, vol. 69, no. 9, 1990, pp. 1191-1199.

[13] V. Moni. „Problematiky zvyšování bezpečnosti při provozování hnědouhelných skládek", in 32. Mezinárodní vědecká konference DIAGO 2013, Rožnov pod Radhoštěm, Czech Republic, 2013, pp. 31-32.

[14] B. Taraba, V. Moni and R. Zíma. "Calorimetric study of basic parameters affecting oxidation of brown coal", in Proc. 13th SGEM GeoConference on Science and Technologies In Geology, Exploration and Mining, Albena, Bulgaria, pp. 273-280.

[15] V. Moni and B. Taraba. „Laboratorní šetření významu základních parametrů ovlivňujících oxidaci hnědého uhlí“, Zpravodaj Hnědé uhli, no. 2, 2013, pp. 17-24.

[16] V. Moni. „Dlouhodobá komplexní měření na hnědouhelné skládce", Zpravodaj Hnědé uhlí, no. 3, 2013, pp. 10-15. 
[17] V. Moni and P. Klouda. „Complex long time measurements carried out on lignite heap on Sokolovské uhelné a. s.", Management Systems in Production Engineering, vol. 10, no. 2, 2013, pp. 27-31.

Ing. Vlastimil Moni, PhD., Ing. Petr Klouda

Brown Coal Research Institute j. s. C., Most

tř. Budovatelů 2830/3, 43401 Most, CZECH REPUBLIC

e-mail:moni@vuhu.cz klouda@vuhu.cz

Ing. Jan Blata, PhD., Doc. Ing. František Helebrant, CSc

VŠB- Technical University of Ostrava

17.listopadu 15, 70833 Ostrava-Poruba, CZECH REPUBLIC

e-mail: jan.blata@vsb.cz

frantisek.helebrant@vsb.cz
[18] V. Moni et al. Výzkum možností predikce vzniku záparů a následného samovznícení hnědouhelných paliv (Rešeršni studie dosavadních poznatků a zkušeností), Most: VUHU, 2011. 